\title{
NOTES ON SOME SKIPPER BUTTERFLIES (LEPIDOPTERA: HESPERIIDAE) FROM PANBARI FOREST AND ITS ADJOINING AREAS, KAZIRANGA-KARBI ANGLONG, UPPER ASSAM, INDIA
}

\section{Monsoon Jyoti Gogoi}

Bokakhat East Dagaon, Dist-Golaghat, P.O. Bokakhat, Assam 785612, India monsoonjyoti@gmail.com

\begin{abstract}
The paper deals with a checklist of 137 species of skipper butterfly (Hesperiidae) along with notes on some species from Panbari Forest, Kaziranga, upper Assam, based on surevy conducted during March 2008-November 2011. Important sightings include Purple Lancer Salanoemia fuscicornis, Red-vein Lancer Pyroneura niasana burmana Evans, 1926, Pied Flat Celaenorrhinus moreana Evans, 1949 and many Choaspes, Potanthus, and Halpe species.
\end{abstract}

Keywords: Butterfly, Kaziranga, northeastern India, Panbari, skipper, upper Assam.

The upper Assam region of northeastern India south to the Brahmaputra River Basin (BRB) is dominated by the Karbi Hills in Golaghat-Karbi Anglong District and the Patkai Range in Dibrugarh-Tinisukia District. The Karbi Hills are isolated from the Patkai Range, which extends through Nagaland into the Cachar Hills of southern Assam. The area is deficient in Lepidoptera surveys in the past. There is some mention of Margherita, Sibsagar and Lumding in upper Assam in European literature, but little taxonomic work has been done and there is no mention of Karbi Hills. Existing taxonomic works on skippers are confined to the neighbouring Khasi and Jaintia hills (Swinhoe 1893, 1896; Cantlie 1956), Cachar hills (Wood-Mason \& de Niceville 1887) and Manipur and Naga hills (Tytler 1915b, 1926b).

\section{Methods}

Study area: Panbari Forest (PF) lying in the foothills of West Karbi Hills is one of the few remaining woodlands left in Assam. The average altitude of the area is around 90m above sea level, varying from around 85-375 $\mathrm{m}$. Part of the forest falling under Golaghat District is protected under Kaziranga National Park (KNP), the rest comes under Kaziranga-Karbi Anglong District and shares its eastern boundary with Dollamora Proposed Reserve Forest (RF) of Kaziranga-Karbi Anglong (Fig. 1).

The area has many Halpe sp. and Potanthus sp., which require dissection of genitalia for identification. These groups have been well studied in Manipur and Naga Hills (Tytler 1915b) and Khasi and Jaintia hills (Cantile 1956), but most other areas of the northeastern hills remain poorly surveyed.

This study was conducted during the period of March 2008 to November 2011 in Panbari Forest, adjoining to Karbi Hills and its neighbouring areas. The complex species were identified on the basis of published literature W.H. Evans (1932, 1949), B.A. Pinratana (1985) and Corbet \& Pendlebury (1992). Halpe sp. and

DOI: http://dx.doi.org/10.11609/JoTT.03340.4759-68 | ZooBank: urn:Isid:zoobank.org:pub:80B6BA6E-4DEE-44CC-ABE3-A79E28E44EDC

Editor: James Young, Hong Kong Lepidopterists' Society, Hong Kong.

Date of publication: 26 September 2013 (online \& print)

Manuscript details: Ms \# 03340 | Received 12 September 2012 | Final received 16 April 2013 | Finally accepted 13 August 2013

Citation: Gogoi, M.J. (2013). Notes on some skipper butterflies (Lepidoptera: Hesperiidae) from Panbari Forest and its adjoining areas, Kaziranga-Karbi Anglong, upper Assam, India. Journal of Threatened Taxa 5(13): 4759-4768; http://dx.doi.org/10.11609/JoTT.03340.4759-68

Copyright: (c) Gogoi 2013. Creative Commons Attribution 3.0 Unported License. JoTT allows unrestricted use of this article in any medium, reproduction and distribution by providing adequate credit to the authors and the source of publication.

Funding: Self funded.

Competing Interest: Authors declare no competing interest.

Acknowledgements: The research on Panbari woodland was only possible due to ex-director of Kaziranga National Park, S.N. Buragohain, who allowed me to carry on work in Panbari forest. On the field, Jogen Das, ex beat officer of Panbari Forest along with his son Tapan Das helped me on many occasions for which I am grateful. 


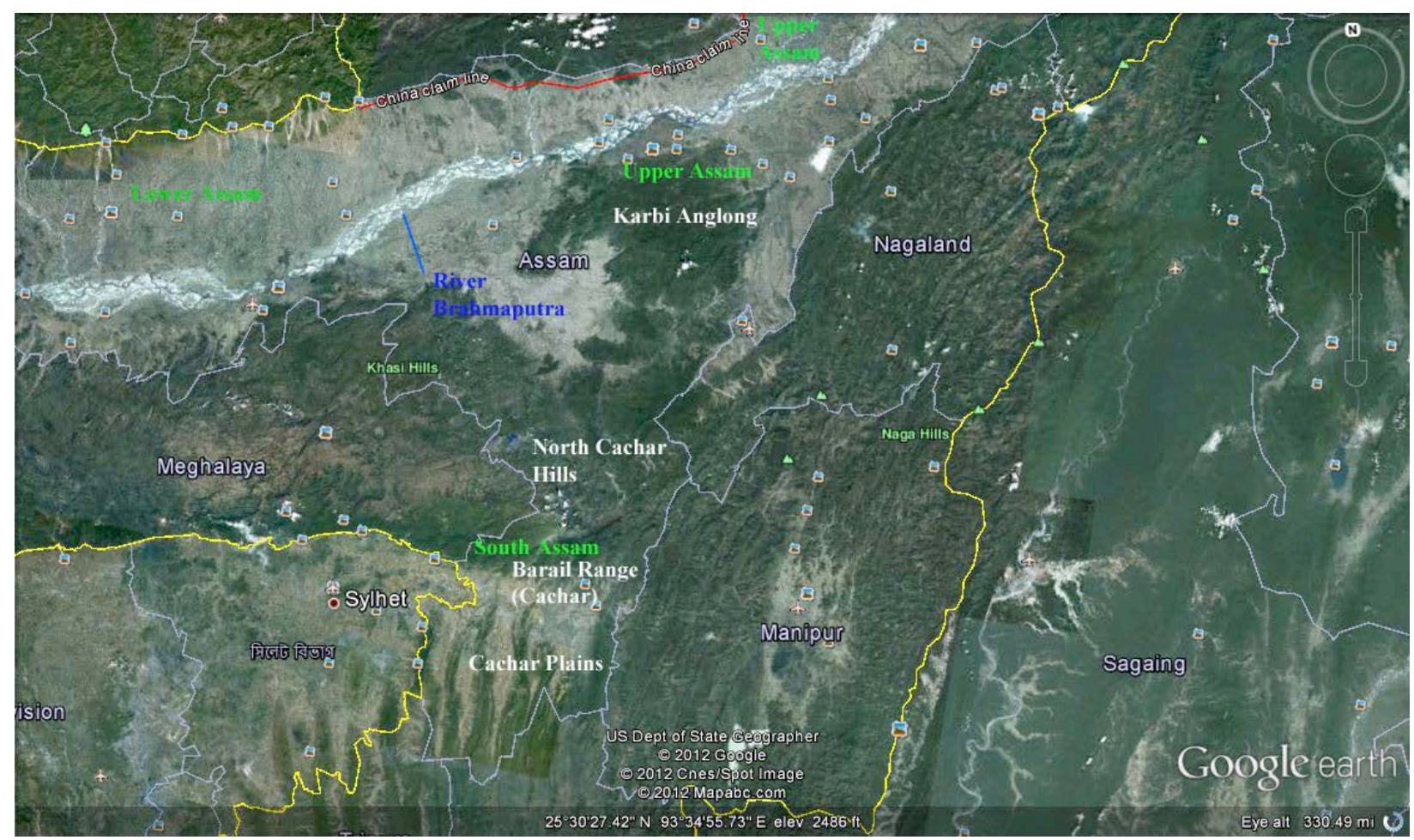

Figure 1. Map showing Upper Assam and South Assam

Potanthus sp. need examination of male genitalia to confirm identity, and due to lack of permission this could not be done.

\section{Results}

A total of 137 species were encountered (Table 1). Important sightings include Purple Lancer Salanoemia fuscicornis, Red-vein Lancer Pyroneura niasana burmana Evans, 1926, Pied Flat Celaenorrhinus moreana Evans, 1949 etc., and lots of Choaspes sp., Potanthus sp. and Halpe sp. The Pied Flat Celaenorrhinus moreana record was interesting because its known only from one specimen collected by Tytler (1915b) from Manipur, which was later described by Evans in 1949.

\section{Notes on selected species/genus}

Branded Awlking Choaspes plateni stigmata Evans, 1932 (Images 1-2): The species was encountered a few times in PF. The main identification key of this species is that the orange tornus on the underside of the wing extends to V3 and continues over the vein. The male is basally dark iridescent green from above, rest indigo blue and female is paler from upperside.

Range: It is distributed in Sikkim, Assam, northern Thailand, Laos, Vietnam, China, Hainan.

Choaspes plateni caudata Evans, 1932 (Images 3-4): One female was encountered on 23 September 2008.
Another male was encountered on 02 July 2009. The tornal area is yellow and the yellow area reaches V3. It has not been reported from northeastern India and is placed under C. stigmata as a subspecies (Evans 1932).

Range: It is known to occur from southern Myanmar, Thailand, western Malaysia, Singapore, Borneo, Sumatra, Nias, Bangka and is placed under $C$. stigmatus as taxon caudatus (Inayoshi 1996-2011).

Indian Awlking Choaspes benjaminii japonica Murray, 1875 (Images 5-6): One male was encountered mud-puddling on a rainy day on 30 August 2008. The species was found flying in PF on many occasions. The species is dark shining indigo blue in new specimens on the upper side of forewing in male, whereas in female, the upper side is dark shining green bases iridescent. Underside of the wing, the tornal orange area does not reach V3 and never near V3.

Range: It is known to occur from western Himalayas, Nepal, Sikkim, Assam, Myanmar, Thailand, Laos, Vietnam, China, Formosa, Palawan.

Hooked Awlking Choaspes hemixanthus furcata Evans, 1932 (Images 7-8): On 20 September 2008, one individual was encountered. The species can be differentiated from $C$. benjaminii japonica in having the basal half dark olive green on the upper side of forewing and outer part brown washed indigo, in male and female, they are paler and brighter. In the male of 
C. benjamnii japonica, the upper side of forewing is dark shining indigo blue, but old specimens turn green. On the underside of the wing, the tornal orange area does not reach V3, but sometimes reaches near V3.

Range: The species is known to occur from Nepal, Sikkim, Assam, Myanmar, Thailand, Laos, Vietnam, Hainan, China, western Malaysia, Palawan.

Large Banded Awl Hasora khoda coulteri Wood Mason \& De Nicéville, 1887 (Image 9): The species has been recorded from Cachar, Assam of northeastern India. One male and female were sighted during field study. The species differ from $H$. taminatus in having a straight postdiscal band on the forewing, whereas in the latter the post discal band is curved inward at costa.

Range: It is known to occur from Assam, Myanmar, Andamans, Thailand (Inayoshi 1996-2011).

Slate Awlet Bibasis mahintha Moore, 1866 (Image 10): One individual, probably a female was encountered in PF. The specimen encountered was pale brown. The species was seen also another time in flight. The species is reported from Silcuri, Cachar of northeastern India (Wood-Mason \& de Nicéville, 1887). The species is recorded from Sebong, Manipur in fair numbers but reported not common (Tytler 1915b).

Range: Assam-Manipur, Burma.

Pied Flat Celaenorrhinus moreana Evans, 1949 (Image 11): The species was recorded only once from PF. The species was first collected from Saitu, Manipur and was thought to be possibly $C$. sumitra but did not have the orange discal spots on the upper side hind wing in Moore's type specimen which was checked by Major W.H. Evans (Tytler 1915b). Other than this, there is no record of the species from northeastern India or any other place. This is probably the second record of the species.

Range: Manipur, Assam

Olive Flat Chamunda chamunda Moore, 1866 (Image 12): This species was previously placed under Celaenorrhinus is now placed under a new genus Chamunda Evans, 1949. The species matches the figure of Lepidoptera Indica Volume 10, but differs in having brown cilia instead of yellow-brown cilia. The species has no spots on the hind wing. The species is reported very common in Sebong, Manipur during March, April and June (Tytler 1915b).

Range: The species is distributed in Sikkim, Myanmar, Thailand, Laos, Malay Peninsula. The species is reported from Sylhet, Sikkim, Assam, Naga Hills (Swinhoe 19121913).

Swinhoe's Flat Celaenorrhinus zea Swinhoe, 1909 (Image 13): The species was encountered around 10 times in PF. Also, it was encountered from Khalingduar RF of Manash Biosphere Reserve, north bank of Brahmaputra River basin. It is a rare species (Swinhoe 1912-1913).

Range: The species is distributed from Sikkim-Assam -Burma (Evans 1949).

Purple Lancer Salanoemia fuscicornis Elwes \& Edwards, 1897 (Image 14): The species is so far known to occur only in southern Assam Hills of northeastern India. Salanoemia fuscicornis was recorded from Cachar and northeastern India (de Nicéville 1887). The specimen from Cachar was however confused to be $S$. submaculata. The species was not rare in PF. The species recorded from PF is interesting because Karbi Anglong and Cachar are the oldest forests in northeastern India and there is no record from any other locality. The specimens qualify to be $S$. fuscicornis as antenna is white ringed mid club (Evans 1932), while antenna is yellow ringed mid club in S. sala. The key to the identification of the male individuals is the upper side forewing with one or two sub-apical spots (Jong 2006). The specimens encountered in PF lacks sub-apical spots on the underside of the wing. It could be due to the fact that subapical spots of upper side may not be visible on underside of the wing.

Range: The species distribution range is from Cachar of Assam to S. Burma, Malaya, Siam, Pulo Laut (Evans 1932).

Red-vein Lancer Pyroneura niasana burmana Evans 1926 (Image 15): On the underside of hind wing, the veins are red in this species and upper side of hind wing, tornus dark brown and on the upper side of forewing, cell spots one above the other, lower hardly produced towards the base (Evans 1932). But, in the specimen encountered the tornus was yellow instead of brown. The species has been recorded only from Cachar, Assam in northeastern India. Cantile (1956) reports P. callineura from Khasi Hills which is probably $P$. niasana burmana. The species was encountered twice in PF during the course of study.

Range: The species is distributed in Assam, Myanmar, Thailand, Langkawi, Malaysia, Borneo, Sumatra, Palawan.

Yellow-vein Lancer Pyroneura margherita margherita Dohertyi, 1889 (Image 16): The species was common in PF although reported very rare (Evans 1932). One male from Margherita (type locality) and similar one from Sadia (the only record of the species from northern bank of River Brahmaputra) was collected by Doherty (Swinhoe 1912-1913). However, the species is recently reported from Pakhui TR of eastern Arunachal 
Pradesh, another record from northern bank (http:// www.ifoundbutterflies.org/309-pyroneura/pyroneuramargherita). The species is reported from Irang River, Manipur (Tytler 1915b). The species is probably absent in Khasi Hills, Meghalaya (the most studied area from northeastern India) as the species is not reported by Swinhoe (1912-1913), Cantile (1956). The species is sighted from Namdapha, western Arunachal Pradesh (Kehimkar 2008). I personally saw the species few times at Jeypore RF, upper Assam, during 2011. The identification key of the species is yellow veins on the underside of hind wing and cell spots conjoined or nearly so (Evans 1932).

Range: The species is distributed from eastern Arunachal Pradesh-upper Assam and western Arunachal Pradesh-Tenasserim.

Yellow-band Palmer Lotongus sarala sarala De Nicéville, 1889 (Image 17): The species was sighted around 20 times during the course of the study and is not rare in PF. The subspecies is only reported from Khasi Hills (Swinhoe 1912-1913) and rare (Evans 1932). The species is however reported from Gasapani, Naga hills at $518 \mathrm{~m}$ and very rare (Tytler 1915b). There is no present sighting of the species in northeastern India.

Range: Assam, Meghalaya (subspecies sarala), Bhamo (subspecies conjuncta), western China, Tonkin (subspecies chinensis), Hainan (subspecies quinquepunctata).

Malay Forest Bob Scobura phidita Hewitson, 1886 (= martini) (Images 18-19): The species was recorded only once in PF. This is the second record of the species from upper Assam, first sighted from Jeypore RF by the author. However, both the races seem to be quite different. The species has also been reported from Nichuguard of Nagaland and western Manipur (Tytler 1915b). The species is also reported from Khasi Hills (Cantile 1956) and since the previous works do not mention the species in Khasi Hills, it appears to be very rare. The identification key of the species can be differentiated from $S$. cephala in spot in 4 absent on upper side of forewing. Underside of hind wing spots black edged and often a discal row of black spots and two spots in cell also black (Evans 1932). The species recorded in PF exactly matches Evans's description, whereas in the specimen that was encountered by the author in Jeypore RF, discal row of black spots on the underside of hind wing were absent.

Range: The species occurs in the southern bank of Brahmaputra River basin. The species is reported from Khasi Hill-Manipur-Myanmar, Malay Peninsula, Sumatra and Borneo.
Forest Bob Scobura cephala Hewitson, 1876 (Image 20): The species was seen more than 20 times in PF. The species was also seen in degraded forest of Dollamora. The species is not rare in northeastern India. On the upper side of forewing, there is a spot in space 4 . On the underside of hind wing, there may be 3 small white spots in 1c, 3 and 6 (absent in the specimen) against the larger spot in 2, 4-5, which are often chestnut edged. In the female, the chestnut colour is very pronounced and occupies the whole area from the spots to tremens and also on the apex of forewing. The species is very similar to $S$. isota but can be distinguished by the present of a conspicuous rectangular spot in space 1 on underside of hind wing (Jong 2006).

Range: The species is distributed from Sikkim to Burma, Malay Peninsula, Sumatra and Borneo.

Large Forest Bob Scobura cephaloises cephaolides De Nicéville, 1888 (Image 21): The species was sighted more than 15 times in PF. The species was seen at Dollamora. The species have basal half yellow and outer half chestnut and small dark ringed white spots in 1c, 2, 3, 5, 6 and sometimes dark spot base 7 on the underside of hind wing (Evans 1932). But, in the specimens of PF and also in Jeypore RF of Assam, an extra spot in space 7 was found by the author; on the contrary, in the specimens recorded by the author from Mishmi Hills, the basal spot in 7 as well as the discal spot in space 7 were both absent. The species is not rare in northeastern India.

Range: The species is distributed from Sikkim to Burma, Tonkin, Hainan. Susbpecies S. cephaloides kinka Evans, 1949 occurs in China (Fan et al. 2010).

Purple Spotted Flitter Zographetus ogygia ogygia Hewitson, 1886 (Image 22): The species was seen more than 10 times in 4-5 October 2008. The species was not seen in other seasons after that. The species bears a prominent discal row of purple brown spots in 1-7 and mid-cell and the subspecies is extremely variable in size, colour of underside, and spots of underside hind wing, which are usually large and diffused (as in the specimen), but may be separate and sharply defined (Evans 1932).

Range: It is distributed in Sikkim to Myanmar, Thailand, Laos, Langkawi, Malaysia, Tioman, Singapore, Borneo, Sumatra, Nias, Banka, Java.

Redeyes Matapa spp.: Five species of Matapa were recorded during the field study. Identification of Matapa was based on the keys of Jong (1983) based on male sex brand and other morphological characters. These are: (i) Common Redeye Matapa aria Moore, 1866, (ii) Purple Redeye Matapa purpurascens Elwes \& Edwards, 1897, (iii) Dark-brand Redeye Matapa druna Moore, 1866, (iv) Black-veined Redeye Matapa sasivarna Moore, 1866, 
Table 1. A preliminary checklist of skippers recorded in Panbari Forest of Kaziranga and neighbouring areas of Karbi Hills (2008-2012)

\begin{tabular}{|c|c|c|}
\hline \multicolumn{2}{|c|}{ Family: Hesperiidae } & \multirow{2}{*}{$\begin{array}{l}\text { Comments } \\
\text { Occurs in Panbari and woodlands of Bokakhat }\end{array}$} \\
\hline 1 & Common Awl Hasora badra Moore, 1858 & \\
\hline 2 & Plain Banded Awl Hasora vitta vitta Butler, 1870 & Seen about four times \\
\hline 3 & Large Banded Awl Hasora khoda coulteri Wood-Mason \& de Nicéville, 1887 & One male and another female seen \\
\hline 4 & White-banded Awl Hasora taminatus bhavara Fruhstorfer, 1911 & Seen in woodlands of Bokakhat, Dollamora \\
\hline 5 & Common Banded Awl Hasora alexis Fabricius, 1775 & Not rare, seen in small woodlands also \\
\hline 6 & Brown Awl Badamia exclamations Fabricius, 1775 & Seen only once \\
\hline 7 & Branded Orange Awlet Bibasis oedipodea aegina Plötz, 1884 & Seen in Panbari and woodlands of Bokakhat \\
\hline 8 & Orange Awlet Bibasis harisa Moore, 1865 & One seen in a hill stream \\
\hline 9 & Slate Awlet Bibasis mahintha Moore, 1866 & Seen twice in Panbari \\
\hline 10 & Small Green Awlet Bibasis amara Moore, 1866 & Seen in Panbari and Kohora \\
\hline 11 & Pale Green Awlet Bibasis gomata Moore, 1865 & One dead specimen encountered \\
\hline 12 & Orange-tail Awl Bibasis sena uniformis Elwes \& Edwards, 1897 & One seen under a leaf in Panbari \\
\hline 13 & Indian Awlking Choaspes benjaminii japonica Murray, 1875 & Seen once at Panbari \\
\hline 14 & Branded Awlking Choaspes plateni stigmata Evans, 1932 & Seen many times at Panbari \\
\hline 15 & Choaspes plateni caudata Evans, 1932 & Seen many times at Panbari \\
\hline 16 & Hooked Awlking Choaspes hemixanthus furcata Evans, 1932 & Seen many times at Panbari \\
\hline 17 & Chamunda chamunda Moore, 1866 & Seen three times at Panbari \\
\hline 18 & Swinhoe's Flat Celaenorrhinus zea Swinhoe, 1909 & Seen about 10 times in Panbari \\
\hline 19 & Pied Flat Celaenorrhinus moreana Evans, 1949 & Seen once in Panbari \\
\hline 20 & Dark Yellow Banned Flat Celaenorrhinus aurivittata Moore, 1879 & Not rare in Panbari \\
\hline 21 & Large Snow Flat Tagiades gana Moore, 1866 & Not rare \\
\hline 22 & Suffused Snow Flat Tagiades japetus obscurus Mabille, 1876 & Common but occurs only in forest \\
\hline 23 & Common Snow Flat Tagiades japetus ravi Moore, 1866 & Common and occurs in villages also \\
\hline 24 & Spotted Snow Flat Tagiades menaka Moore, 1866 & Seen twice at Panbari \\
\hline 25 & Water Snow Flat Tagiades litigiosa Möschler, 1878 & Occurs in woodlands of Bokakhat, common at Panbari \\
\hline 26 & Yellow Flat Mooreana trichoneura pralaya Moore, 1865 & Not rare in Panbari, also seen in Kanchanjuri \\
\hline 27 & Dusky Yellow-breast Flat Gerosis phisara Moore, 1884 & Common at Panbari, Dollamora \\
\hline 28 & $\begin{array}{l}\text { Fulvous Pied Flat } \alpha \text { Pseudocoldaenia dan faith Kollar } \\
\beta \text {. dhyana Fruhstorfer, } 1909\end{array}$ & Very common species \\
\hline 29 & Sikkim White Flat Seseria sambara Moore, 1865 & Seen about six times at Panbari \\
\hline 30 & Himalayan White Flat Seseria dohertyi Watson, 1893 & Seen once at Panbari \\
\hline 31 & Chestnut Angle Odontoptilum angulata Felder, 1862 & Not rare in occurance \\
\hline 32 & Grey Pied Flat Coladenia laxmi laxmi de Nicéville, 1889 & Seen a few times at Panbari \\
\hline 33 & Brown Pied Flat Coladenia agni de Nicéville, 1883 & $\begin{array}{l}\text { Nor rare in occurrence but seen only in one area regularly } \\
\text { at Panbari }\end{array}$ \\
\hline 34 & Elwes Pied Flat Coladenia agnioides Elwes \& Edwards 1897 & Seen once in Panbari \\
\hline 35 & Common Small Flat Sarangesa dasahara Moore, 1865 & Occurs un urban areas \\
\hline 36 & Indian Skipper Spialia galba Fabricius, 1793 & Occurs in forest edges, very common \\
\hline 37 & Tiger Hopper Ochus subvittatus subradiatus Moore, 1878 & One seen by Gaurab Nandai Das in Bokakhat \\
\hline 38 & Giant Hopper Apostictopterus fuliginosus Leech, 1893 & One seen at Numaligarh RF \\
\hline 39 & Forest Hopper Asticopterus jama olivascens Moore, 1878 & Occurs in open edges of forest \\
\hline 40 & Bush Hopper Ampittia dioscorides Fabricius, 1793 & $\begin{array}{l}\text { Occurs in open edges of forest and grasslands, very } \\
\text { common at Dollamora }\end{array}$ \\
\hline 41 & Scarce Bush Hopper Ampittia maroides de Nicéville, 1896 & Seen few times at Kakochang, Dollamora \\
\hline 42 & Blue-spotted Scrub Hopper Aeromachus kali de Nicéville, 1885 & One seen at Kakochang and another at Bokakhat \\
\hline 43 & Aeromachus stigmata obsoleta Moore, 1878 & Common in villages \\
\hline 44 & Aeromachus jhora creta Evans, 1949 & Common in the paddy field areas of Kohora \\
\hline 45 & Pigmy scrub Hopper Aeromachus pygmaeus Fabricius, 1775 & Seen few times at Numaligarh RF \\
\hline 46 & Chestnut Bob lambrix salsala Moore, 1865 & Very common \\
\hline 47 & Indian Palm Bob Suastus gremius gremius Fabricus, 1878 & Seen only once at Panbari \\
\hline 48 & Small Indian Palm bob Suastus minuta aditia Evans, 1943 & Seen many times at Panbari \\
\hline
\end{tabular}




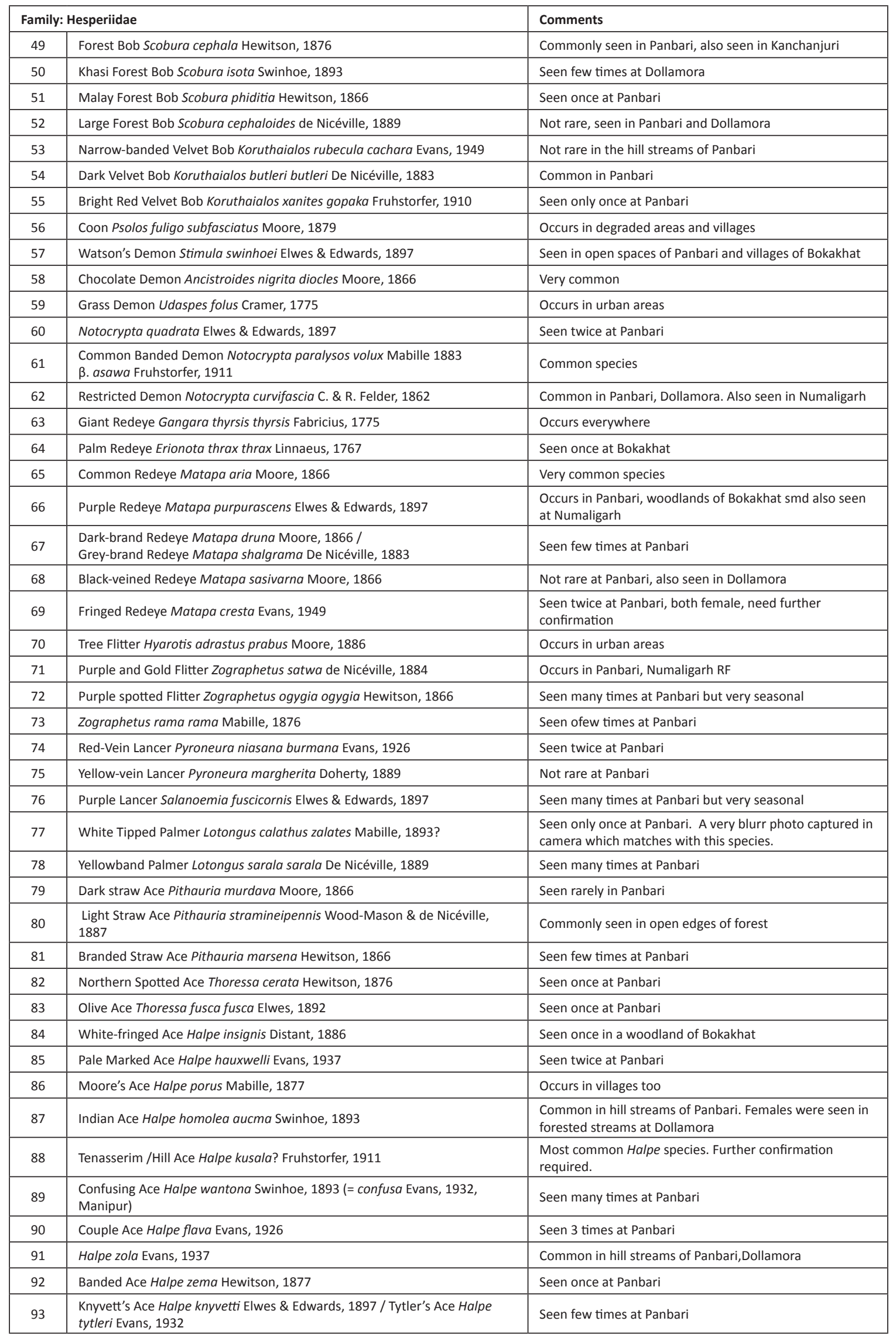




\begin{tabular}{|c|c|c|}
\hline \multicolumn{2}{|c|}{ Family: Hesperiidae } & \multirow{2}{*}{$\begin{array}{l}\text { Comments } \\
\text { Seen once mud-puddling in Panbari }\end{array}$} \\
\hline 94 & Sikkim Ace Halpe sikkima Moore, 1882 & \\
\hline 95 & Halpe arcuata Evans, 1937 & Seen once at Panbari \\
\hline 96 & Wax Dart Cupitha purreea Moore, 1877 & Seasonally common \\
\hline 97 & Common Dartlet Oriens gola Moore, 1877 & Very common species and occurs in urban areas also \\
\hline 98 & Branded Dart Potanthus rectifasciata rectifasciata Elwes \& Edwards, 1897 & Seen once at Panbari \\
\hline 99 & Common Dart Potanthus pseudomaesa clio Evans, 1932 & Seen twice in Panbari \\
\hline 100 & Burmese Dart Potanthus juno Evans, 1932 & $\begin{array}{l}\text { Seen twice at forest of Panbari, once a male, another } \\
\text { time a female }\end{array}$ \\
\hline 101 & Sikkim Dart Potanthus nesta Evans, 1934 & Seen two times at Panbari \\
\hline 102 & Palni Dart Potanthus palnia palnia Evans, 1914 & Seen few times at Panbari \\
\hline 103 & Broad Bident Dart Potanthus trachala tytleri Evans, 1914 & $\begin{array}{l}\text { The species was seen about } 10 \text { times in a hill stream of } \\
\text { Panbari }\end{array}$ \\
\hline 104 & Pallid Dart Potanthus pallida Evans, 1932 & The species was seen once at Panbari \\
\hline 105 & Narrow Bident Dart Potanthus mingo ajax Evans, 1932 & Seen few times at Panbari \\
\hline 106 & Chinese Dart Potanthus confucius dushta Fruhstorfer, 1911 & $\begin{array}{l}\text { The species occurs in Panbari as well as small woodlands } \\
\text { of Bokakhat Seen once at Dollamora and once at Panbari }\end{array}$ \\
\hline 107 & Assam Dart Potanthus lydia lydia Evans, 1934 & Seen once at Panbari \\
\hline 108 & Sumatran Dart Potanthus ganda ganda Fruhstrofer, 1911 & Seen many times at Panbari, male and female together \\
\hline 109 & Yellow Dart Potanthus flava alcon Evans, 1932 & Seen once at Kohora \\
\hline 110 & Potanthus sita Evans, 1932 & Seen few times in a hill stream of Panbari \\
\hline 111 & Common Palm Dart Telicota colon Fabricius, 1775 & $\begin{array}{l}\text { Seen in Panbari and woodlands of Bokakhat. In Panbari, } \\
\text { the species was found in hill streams. Was found to bask } \\
\text { in the sun. }\end{array}$ \\
\hline 112 & Dark Palm Dart Telicota bambusae Moore, 1878 & $\begin{array}{l}\text { Males were seen a few times in hill streams of Panbari. } \\
\text { Was found to bask in the sun. Females were seen in the } \\
\text { forest. }\end{array}$ \\
\hline 113 & Dark Palm Dart Telicota ohara jix Evans, 1949 & $\begin{array}{l}\text { The species was seen few times in Panbari forest, was } \\
\text { found fond of shady areas, never opened their wing }\end{array}$ \\
\hline 114 & Besta Palm Dart Telicota besta bina Evans, 1949 & Males were seen visiting hill streams at Panbari \\
\hline 115 & Greenish Palm Dart Telicota ancilla horisha Evans, 1934 & $\begin{array}{l}\text { Males were seen few times mud-puddling and basking in } \\
\text { the hill streams of Panbari }\end{array}$ \\
\hline 116 & Linna Palm Dart Telicota linna linna Evans, 1949 & Seen few times at Panbari \\
\hline 117 & Plain Palm Darts Cephrenes acalle Hopffer, 1874 & Commonly seen in the woodlands of Bokakhat \\
\hline 118 & Common Wight Iton semamora semamora Moore, 1866 & One seen by Bitupon Boruah in Kohora in November \\
\hline 119 & Paintbrush Swift Baoris farri Moore, 1878 & Common in Panbari \\
\hline 120 & Small Paintbrush Swift Baoris penicilliata chapmani Evans, 1937 & Seen sometimes at Panbari \\
\hline 121 & Figure of 8 Swift Caltoris pagana De Niceville, 1887 & Rare in Panbari, once seen near a hill stream \\
\hline 122 & Yellow Fringed Swift Caltoris aurociliata Elwes \& Edwards, 1897 & $\begin{array}{l}\text { Commonly seen in the woodlands of Bokakhat, seen } \\
\text { rarely at Panbari }\end{array}$ \\
\hline 123 & Sirius Swift Caltoris sirius Evans, 1926 & Not rare in Panbari \\
\hline 124 & Colon Swift Caltoris bromus Leech, 1894 & Not rare \\
\hline 125 & Colon Swift Caltoris cara Evans, 1932 & Not rare \\
\hline 126 & Full stop Swift Caltoris moolata Moore, 1878 & A female seen at Dollamora \\
\hline 127 & Tufted Swift Caltoris plebeia de Nicéville, 1887 & Seen few times in a woodland of Bokakhat \\
\hline 128 & Blank Swift Caltoris kumara moorei Evans, 1926 & Seen on Panbari and also in paddy fields of Kohora \\
\hline 129 & Phillipine Swift Caltoris philippina belli Evans, 1932 & Seen few times in the woodlands of Bokakhat \\
\hline 130 & Contiguous Swift Polytremis lubricans Herrich-Schäffer, 1869 & Commonly seen everywhere \\
\hline 131 & Great Swift Pelopidas assamensis de Nicéville, 1882 & Occurs on degraded forest \\
\hline 132 & Conjoined Swift Pelopidas conjuncta javana Mabille, 1877 & Not rare \\
\hline 133 & Large Branded Swift Pelopidas sinensis Mabille, 1877 & Very common species \\
\hline 134 & Small Branded Swift Pelopidas mathias Fabricius, 1798 & Very common species \\
\hline 135 & Straight Swift Parnara guttatus Bremer \& Grey, 1852 & Common everywhere \\
\hline 136 & Ceylon Swift Parnara bada Moore, 1878 & Common species \\
\hline 137 & Bevan's Swift Pseudoborbo bevani Moore, 1878 & Seen twice in Panbari \\
\hline
\end{tabular}






Image 1. Choaspes plateni stigmata Evans, 1932 (male)

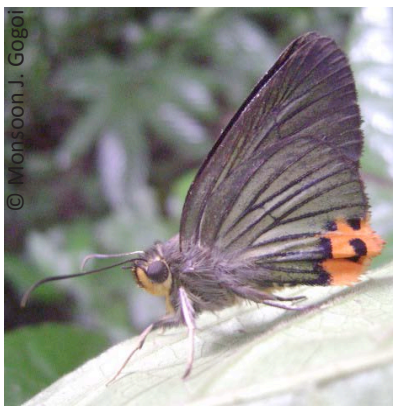

Image 5. Choaspes benjaminii japonica Murray, 1875

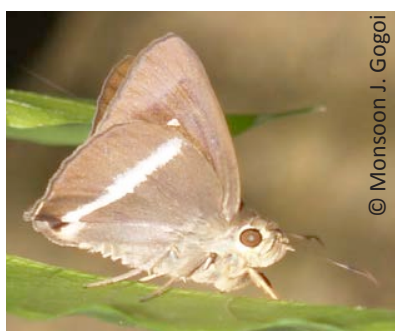

Image 9. Hasora khoda coulteri Wood Mason \& De Nicéville, 1887 (female)



Image 13. Celaenorrhinus zea Swinhoe, 1909

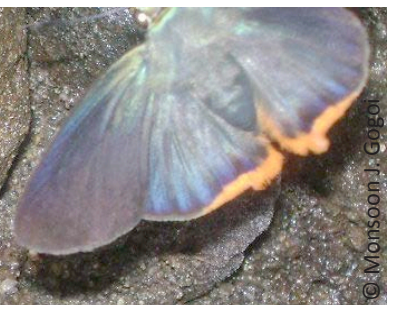

Image 2. Choaspes plateni stigmata Evans, 1932 (male upper side)

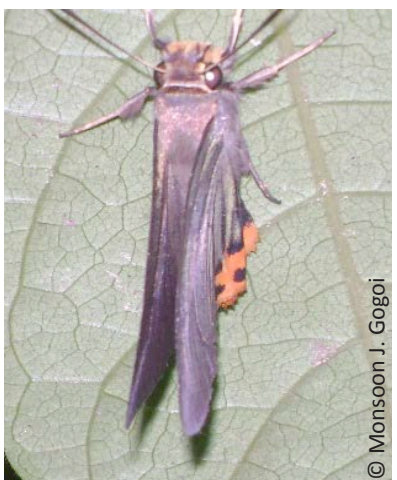

Image 6. Choaspes benjaminii japonica Murray, 1875 (upper side)

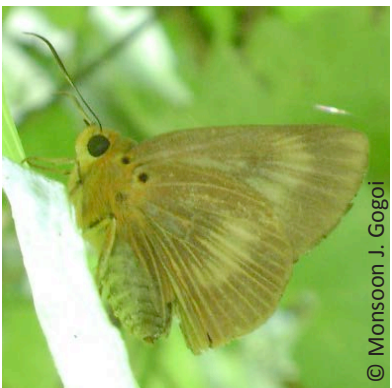

Image 10. Bibasis mahintha Moore, 1866

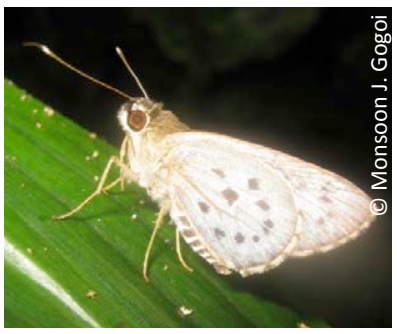

Image 14. Salanoemia fuscicornis Elwes \& Edwards, 1897

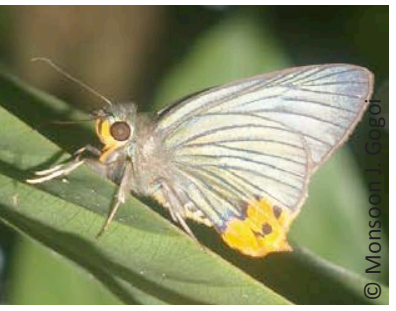

Image 3. Choaspes plateni caudata Evans, 1932 (male)

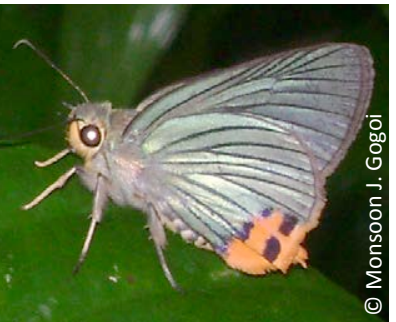

Image 7. Choaspes hemixanthus furcata Evans, 1932

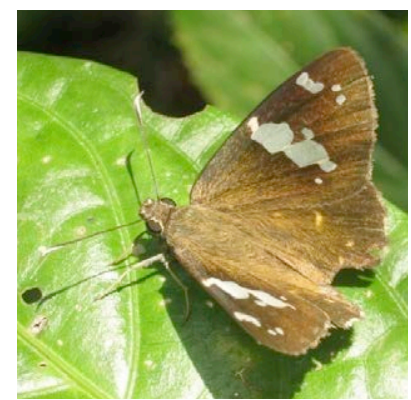

Image 11. Celaenorrhinus moreana Evans, 1949

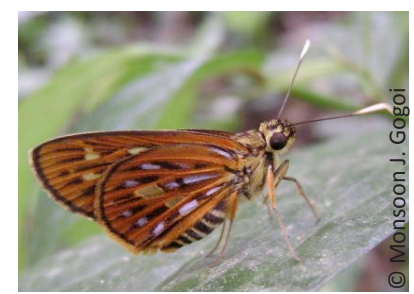

Image 15. Pyroneura niasana burmana Evans, 1926

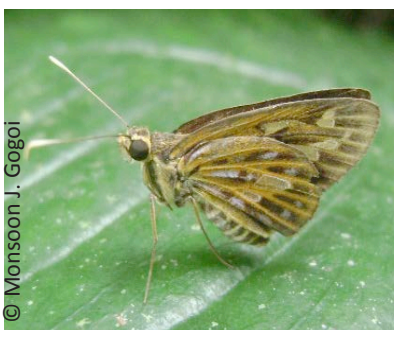

Image 16. Pyroneura margherita margherita Dohertyi, 1889

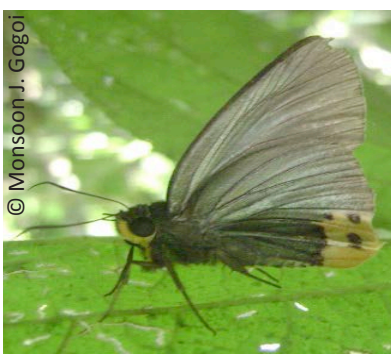

Image 4. Choaspes plateni caudata Evans, 1932 (female)

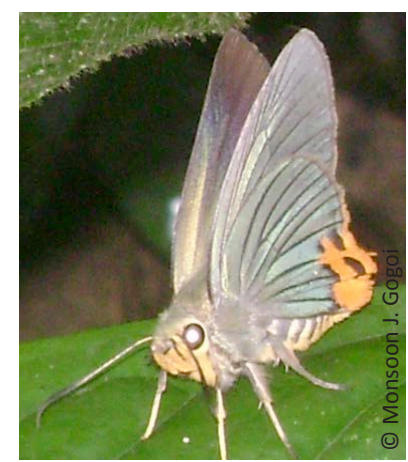

Image 8. Choaspes hemixanthus furcata Evans, 1932 (upper side)

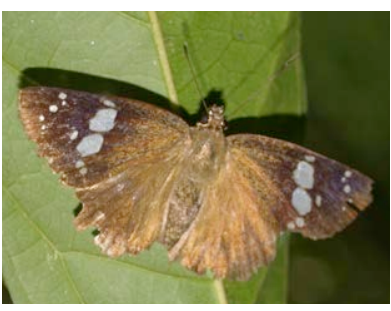

Image 12. Chamunda chamunda Moore, 1866

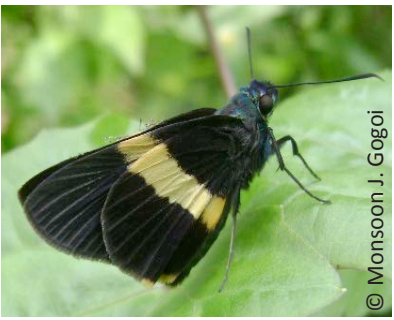

Image 17. Lotongus sarala sarala De Nicéville, 1889

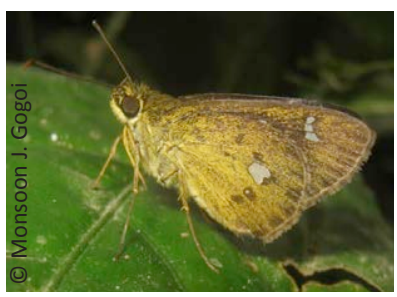

Image 18. Scobura phidita Hewitson, 1886 

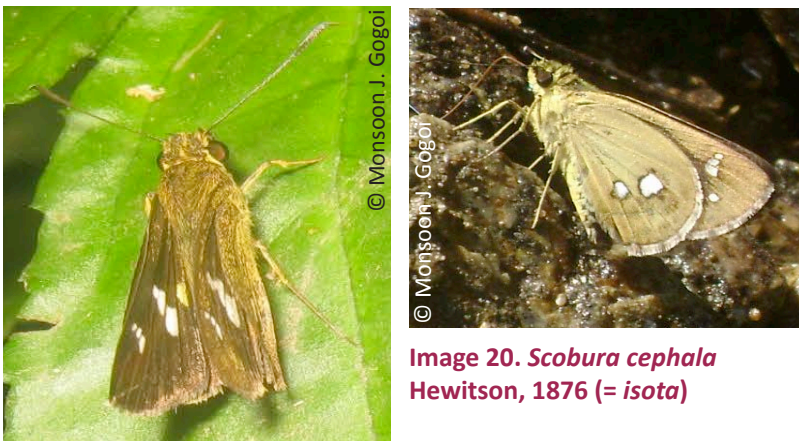

Image 20. Scobura cephala Hewitson, 1876 (= isota)

Image 19. Scobura phidita Hewitson, 1886 (upper side)

(v) Fringed Redeye Matapa cresta Evans, 1949. All these five species were previously reported from Khasi Hills (Cantile 1956). Matapa aria was found abundant everywhere. Matapa purpurascens could be found in village woodlands of Bokakhat. Others were found in primary forests of Panbar and Dollamora.

Darts Potanthus spp.: A total of 13 Darts were identified based on identification keys of Evans (1932), Evans (1949), Pinratana (1985) and Corbet \& Pend lebury ( 1992). However, identification of Potanthus species are challenging and need dissection of genitalia for confirming the species. Earlier taxonomic work on Potanthus is well studied from Khasi Hills with 11 species (Cantile 1956). Species they were recorded during field study were possibly : (i) Branded Dart Potanthus rectifasciata rectifasciata Elwes \& Edwards, 1897, (ii) Pallid Dart Potanthus pallida Evans, 1932, (iii) Broad Bident Dart Potanthus trachala tytleri Evans, 1914, (iv) Common Dart Potanthus pseudomaesa clio Evans 1932, (v) Burmese Dart -Potanthus juno Evans 1932, (vi) Sita Dart Potanthus sita Evans, 1932 (vii) Yellow Dart Potanthus flava alcon Evans, 1932, (viii) Chinese Dart Potanthus confucius dushta Fruhstorfer, 1911, (ix) Sikkim Dart Potanthus nesta Evans, 1934 , (x) Narrow Bident Dart Potanthus mingo ajax Evans, 1932, (xi) Assam Dart Potanthus lydia lydia Evans, 1934, (xii) Sumatran Dart Potanthus ganda ganda Fruhstrofer, 1911, (xiii) Palni Dart Potanthus palnia palnia Evans, 1914.

Aces Thoressa/Halpe spp.: Lots of Halpe spp. were encountered during field study. However, they need dissection of male genitalia for confirming their identity. Moreover, more taxonomic work is needed in this group from northeastern India. The following species were identified on the basis of identification keys: (i) Whitefringed Ace Halpe insignis Distant, 1886, (ii) Moore's Ace Halpe porus Mabille, 1877, (iii) Indian Ace Halpe homolea, (iv) Overlapped Ace Halpe arcuata Evans, 1937, (v) Tenasserim/Hill Ace Halpe kusala Fruhstorfer,

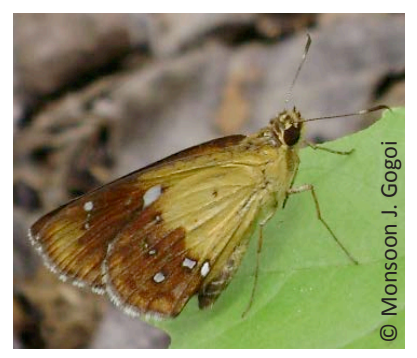

Image 21. Scobura cephaloises cephaolides De Nicéville, 1888

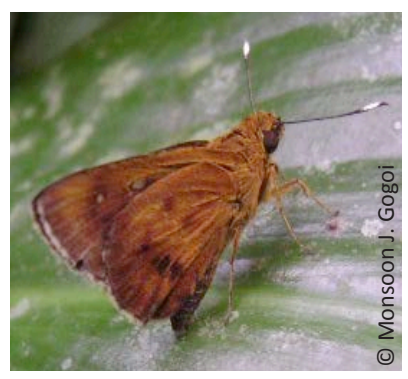

Image 22. Zographetus ogygia ogygia Hewitson, 1886
1911?, (vi) Confusing Ace Halpe wantona Swinhoe, 1893, (vii) Banded Ace Halpe zema, (viii) Halpe zola Evans, 1937, (ix) Knyvett's Ace Halpe knyvetti Elwes \& Edwards, 1897, (x) Sikkim Ace Halpe sikkima Moore, 1882 and (xi) Pale Marked Ace Halpe hauxwelli Evans, 1937. Out of these, Halpe burmana is only reported from Manipur of northeastern India (Tytler 1915b). Two Thoressa species were recorded: (i) Northern Spotted Ace Thoressa cerata Hewitson, 1876 and (ii) Olive Ace Thoressa fusca fusca Elwes, 1892

\section{Discussions}

Purple Lancer Salanoemia fuscicornis, which was reported previously from Cachar of northeastern India, was sighted approximately $200 \mathrm{~km}$ away from Panbari. This record of the species is significant because between Cachar and Panbari there lay two hill ranges: Karbi Anglong (Karbi Hills) and North Cachar Hills. The species should also be present all along the inaccessible Karbi Hills but is presumed to be absent from North Cachar Hills due to high altitude. The species should also be absent in the northern bank of Brahmaputra, as the basin is a barrier for many Malayan species of butterflies. The species is only reported from Panbari, Kaziranga of upper Assam and hence the distribution pattern is very interesting. The species is probably absent in other parts of upper Assam dominated by Patkai Range, i.e., Dibrugarh and Tinisukia District. Much of northeastern Hills (Dibrugarh District of upper Assam and southern Assam are part of Patkai range) is dominated by Patkai range but Karbi Hills remain isolated from this range and hence some species of Patkai and eastern Himalaya are likely to be absent here. Hence, the study was important from bio-geographic point of view.

This study will help to elucidate the importance of lowland forest in northeastern India from a biodiversity prospective. Species such as Salanoemia fuscicornis, which has only been reported from Cachar of Assam 
in northeastern India, was sighted in PF showing the importance of the area. Other than (Cachar, Panbari) Assam of northeastern India, the species is known to occur from southern Myanmar, Malaya, Siam, Pulo Laut. Salanoemia fuscicornis was recorded from low altitude of PF, around $90 \mathrm{~m}$ of sea level. The record of such species from the area shows the importance of conserving the low altitude forest of upper Assam and southern Assam Hills. PF is well protected under KNP while neighbouring forests like Dollamora, which are as significant as Panbari, are facing serious problems of logging and deforestation. Fuel wood extraction is going on regularly and should be stopped. Many stone quarries are also in the making in Dollamora and other accessible areas of KA. An effort should be made to save the last remaining forests in this area. Conservation priority of the woodlands and hills in this area is lacking, with efforts being concentrated on saving the floodplains of Kaziranga National Park.

\section{REFERENCES}

Cantlie, K. (1956). Hesperiidae of Khasi and Jaintea hills. Journal of the Bombay Natural History Society 54: 212-215.

Corbet, A.S. \& H.M. Pendlebury (1992). The Butterflies of the Malay Peninsula, 4th Edition (Revised by J.N. Eliot). Malayan Nature Society, Kuala Lumpur, 595pp.
Jong, R. De. (1983). Revision of the oriental genus Matapa Moore (Lepidoptera, Hesperiidae) with discussion of its phylogeny and geographic history. Zoologische Mededelingen 57: 243-270.

Jong, R. De. (2006). Notes on Salanoemia Eliot, 1978, and Isma Distant, 1886 (Lepidoptera: Hesperiidae), mainly from Java and Sumatra. Tijdschrift voor Entomologie 149: 15-20.

Evans, W.H. (1932). The Identification of Indian Butterflies (2 ${ }^{\text {nd }}$ Edition). Bombay Natural History Society, Mumbai, India, 464pp.

Evans, W.H. (1949). A Catalogue of the Hesperiidae of Europe, Asia and Australia in the British Museum (Natural History). Trustees of the British Museum, London, 502pp.

Fan, X., H. Chibia \& M. Wang (2010). The genus Scobura Elwes and Edwards, 1897 from China, with description of two new species (Lepidoptera: Hesperiidae). Zootaxa 2490: 1-15.

Inayoshi, Y. (1996-2011). A Check List of Butterflies in Indo-China, page on Family Lycaenidae http://yutaka.it-n.jp/lyc4/81565001. html (accessed on 09 February 2012).

Pinratana, B.A. (1985). Butterflies in Thailand, 5 - Hesperiidae. Vinratham Press, Bangkok, 150pp.

Swinhoe, C. (1893). XVIII. A list of the Lepidoptera of the Khasia Hillspart I. Transactions of the Entomological Society of London 41(3): 267-330; http://dx.doi.org/10.1111/j.1365-2311.1893.tb02070.x

Swinhoe, C. (1896). New species of Lepidoptera from Khasia Hills. Annals and Magazine of Natural History, including Zoology, Botany, and Geology 6(17): 357-363.

Swinhoe, C. (1911-1912). Lepidoptera Indica. Part IX. RhopaloceraLycaenidae and Hesperiidae. Lovell, Reeve \& Co. Ltd., London, 278pp.+706-756pls.

Swinhoe, C. (1912-1913). Lepidoptera Indica. Part X. RhopaloceraHesperiidae. Lovell, Reeve \& Co. Ltd., London, 364pp.+757-835pls.

Tytler, H.C. (1915b). Notes on some new and interesting butterflies from Manipur and the Naga Hills-part III. Journal of the Bombay Natural History Society 24: 119-155.

Wood-Mason, J. \& L. de Niceville (1887). List of the lepidopterous insects collected in Cachar by Mr. J. Wood-Mason. Part II. Rhopalocera. Journal of Asiatic Society of Bengal 55(4): 343$393+4$ pls. 